\title{
'JOHN G. LAKE AS A FRAUD, CON MAN AND FALSE PROPHET': CRITICAL ASSESSMENT OF A HISTORICAL EVALUATION OF LAKE'S MINISTRY
}

\section{Marius Nel}

Research Unit of the Faculty of Theology

North-West University

nel.marius1@gmail.com

\section{ABSTRACT}

This article assesses the evaluation of John G. Lake, one of the founders of South African Pentecostalism, by some historians regarded as a fraud, con man and false prophet in terms of several elements of his life: his business concerns; his mission to Africa; ministry of Spirit baptism and divine healing; and some accusations made by Lake's co-workers. The conclusion is reached that there are valid points of criticism against Lake's ministry and concerns about his integrity, although it is also true that the specific historical evaluation is hampered by presuppositions that preclude any miracles and a seemingly preconceived notion of Lake as a fraud and scam, supported by an unbalanced utilisation and unfair treatment of resources.

Keywords: John G. Lake; fraud; falsification; Pentecostalism; divine healing; missions

\section{INTRODUCTION}

The Pentecostal movement started from humble beginnings in 1901 and 1906 and developed into perhaps the most significant religious movement in the twentieth century, with a growth rate of 52000 a day or 19 million a year, as estimated by

\section{UNISA}


David Barrett $(1998,50) .{ }^{1}$ In 1993 the number of Pentecostals and charismatics exceeded 420 million people (Synan 2006, 1) and in 2006 the number exceeded 580 million (Blumhofer 2006, 21), making Pentecostalism the fastest growing branch of Christianity worldwide (Turnage 2003,6). McGee $(2012,35)$ calculates that at the current rate of growth, there will be 1 billion Pentecostals by 2025, with most of them living in Asia, Africa, and Latin America (McGee 2012, 35), presenting the southward swing of the Christian centre of gravity (Anderson, A.H. 2003, 1). ${ }^{2}$ The movement started with classical Pentecostals in Parham's Bible School and at Azusa Street; was perpetuated in the charismatic renewal of the 1960s with Dennis Bennett, Kevin Ranaghan, and Kathryn Kuhlman in Van Nuys, California, only a few kilometres north of Azusa Street (Harper 2008, 108; Tickle 2012, 67-69); and invigorated by the third-wave neo-charismatic movement headed by Peter Wagner and John Wimber (Gabriel, 2012, 150-154; Synan 2001, 177-232). ${ }^{3}$

The international Pentecostal movement originated in a black church in Azusa Street, Los Angeles, led by William Seymour, ${ }^{4}$ son of African slaves (Anderson, R.M. 1979, 60; Anderson, A.H. 2012b, 186) where fifteen hundred people were estimated to have been in attendance on any given Sunday (Letson 2007, 115). Azusa Street was a church with mostly black people, although many white people attended the church led by an unpretentious black man (Lovett 1975, 136) ${ }^{5}$ who was earlier made to suffer the ignominy of sitting outside the classroom door of the Charles Parham's Bible school in Houston (Anderson, A.H. 1997, 2). People flocked to Azusa Street to 'receive the Spirit', ${ }^{6}$ and they left with the message of 'Pentecost' and an evangelistic zeal to share it with the world, reaching more than 50 nations within two years (1906-1908) (MacRobert 1988, 56, 81).

1 'The Pentecostal movement is by far the largest and most important religious movement to originate...This explosive growth has forced the Christian world to pay increasing attention to the entire movement and to attempt to discover the root cause of this growth' (Synan 2006, 1). Pate $(1991,243)$ estimated that the Majority World mission movement was growing at five times the rate of Western missions, resulting in half of the world's Christians living in developing, poor countries.

2 There are approximately 2.18 billion Christians in the world, but Christianity in the West experiences a demise, with Europe's population being 66.3\% Christian in 1910 and $25.9 \%$ in 2013. In South Africa, the Dutch Reformed Church reported membership losses of over 20000 people in just one year (2012) (Joubert 2013, 114). Christianity grew in sub-Saharan Africa from $9 \%$ in 1910 to $63 \%$ in 2010 (Joubert 2013, 114-115).

3 Cp. Cox 1995, 20, 23-25, 34-42.

4 Seymour was a Holiness preacher before he attended Parham's Bible School in Houston, Texas in 1905 (Hammonds 2009, 6).

5 'Such radicality and revolutionary nature of the revival both repulsed and fascinated its critics, both secular and Christian' (Tan-Chow 2007, 45).

6 'The services (at Azusa Street) centered on baptism of the Holy Spirit and did not involve prayer, singing or sermons in the usual sense' (Hammonds 2009, 7). After 1909 the church went into decline and by 1914 the membership was almost entirely black (Synan 1971, 116). 
John G. Lake ${ }^{7}$ visited at Azusa Street in 1907 with Seymour and other Pentecostal leaders (Lake 1981, 32), ${ }^{8}$ and he led a party consisting of Thomas Hezmalhalch, ${ }^{9}$ J.C. Lehman ${ }^{10}$ and others (Synan 2006, 6) with the purpose to bring the message of 'Pentecost' to South Africa. He revisited Azusa Street on at least one further occasion to report to Seymour about the progress of the Pentecostal mission he had led in South Africa (Anderson, A.H. 1997, 3; Lake 1981, 32). When Lake left South Africa in 1913, never to return, his legacy was two Pentecostal groups in South Africa, the Apostolic Faith Mission of South Africa (AFM of SA) and the Zion Apostolic Church (Anderson, A.H. 2007, 7; Synan 1997, 138). ${ }^{11}$ Today a large segment of Christians in South Africa belong to the Pentecostalist tradition (Anderson, A.H. 2000, 14; 2001, 27; Nel 2005, 202-203) with half of them adherents of the Zionist/ Pentecostalist legacy of Lake (Morton 2012a, 98).

In this article the negative evaluation of John G. Lake and his ministry by some historians, as represented by Barry Morton, is presented and discussed.

Barry Morton is associated with Unisa's History Department where he is busy with post-doctoral studies and serves as a research fellow. His interest is concerned with Botswana and southern African history, and he wrote articles on Zionism and the Zionist churches; John G. Lake as one of the founders of the Pentecostal tradition in South Africa; Botswana history and the evolution of women's property rights in colonial Botswana; as well as some issues in Indiana history in conjunction with Elizabeth Morton. In his historical assessment of Lake he represents a smaller school of thinking linked with Murray (1999), Hitchens (2009), and websites like http://letusreason.org. In their evaluation of Lake they warn that not much historical research on Lake and the Pentecostal and Zionist movement has been done, despite the fact that it was by far the most successful southern African religious movement

7 Lake was born at St. Mary's, Ontario Canada, on 18 March 1870 (Susanto and Theron 2008, 173). He died in Spokane on 16 September 1935 (Synan 1997, 138).

8 Lake $(1981,19)$ met Seymour for the first time in 1907, and then commented that Seymour had 'more of God in his life than any man I had ever met'.

9 Hezmalhalch (1847-1934) was born in England and was 60 years of age when he arrived in South Africa.

10 Lehman had visited South Africa before, as a missionary to the Zulus for five years (Synan 2006, 6). Lehman founded the Pentecostal Holiness Church in South Africa in 1913.

11 Lake viewed himself as being an emissary of Seymour's Apostolic Faith Gospel Mission, which placed less stress on divine healing and more on the Holy Spirit. Generally speaking, Lake's African followers were more sympathetic to his Zionist ethos, and his white followers to his Pentecostalism (Morton 2013b, 13). 
of the twentieth century (Morton 2012a, 98). ${ }^{12}$ Where historical research was done about the development and diffusion of the Pentecostal tradition in southern Africa, Morton (2012a, 99) claims, it occurred from a Pentecostal or Evangelical perspective, and academics treated it with 'kid gloves' ${ }^{13}$ Lake is seen as divinely inspired, directly sent by God to southern Africa, orchestrating massive healing campaigns using the laying on of hands to cure various diseases and infirmities, and performing other miracles such as resurrecting the dead. ${ }^{14}$ Lake's legacy in the AFM and the African Pentecostal churches is evaluated as 'innately positive developments' (Landau 2010, 184). In the process of advocating Pentecostals' own agenda, John G. Lake is not seen for what he in fact was, a con man 'who consciously used deception both to gain tithe-paying adherents, and to defraud and control them once they were in his organization' (Morton 2012a, 99). Morton (2012a, 100) concludes that the centre of Lake's religious activities consisted of consciously deceiving people (Morton 2012a, 100). This conclusion implies that Lake's activities 'seriously call into question' (Morton 2012a, 100) the characterisation of the Pentecostal and Zionist movement that Lake founded and make a mockery of its allegedly divine inspiration. The arguments will now be investigated in terms of different aspects of Lake's life and ministry.

12 However, Morton's bibliographies in his articles betray that he is not knowledgeable about the many works reflecting research into the origins and development of the Pentecostal and Zionist traditions in southern Africa. Scholars like A.H. Anderson (1991, 1992, 1997, 2000, 2001, 2007), Asamoah-Gyadu (2002, 2013a, 2013b), Berglund (1976), Burger (1987, 1997), Burger and Nel (2008), Comaroff (1985), Daneel (1971), De Wet (1989), Liardon (1996, 1999), Lindsay (1972), Oosthuizen (1987), Reidt (1989), Sundkler (1976), and Synan (1971, 1997, 2001, 2006) should be mentioned. Lindsay worked with John G. Lake's evangelistic campaigns and, during 1948, with William Branham (Bundy 1990, 341).

13 Morton (2014b, 1) warns that his work about Lake is 'not a labor of love;' rather, it is a 'muchneeded corrective to a host of misleading writings that many other faith healing con men have invoked in order to increase the charismatic nature of their healing ceremonies.' Morton (2014b, 4) finds in Lake's own writings and sermons 'rarely any honesty', a remark that he does not motivate in any way.

14 Lake (among others) 'prioritized seeking for spectacular displays of celestial powers - signs and wonders, healing, and deliverance from sinful habits and satanic bondage' (McGee 1997, 329). The numerous healings were viewed as confirmation that God's Word was true, his power was evidently on the missionary efforts, and the result was that many were persuaded to become Christians (Anderson, A.H. 2003, 6). At the turn of the previous century, most mainline or traditional churches in South Africa did not minister healing (Susanto and Theron 2008, 170). Specifically within the Reformed tradition the ministry of healing was not expected, and even denied. The development of divine healing became one of the hallmarks of early Pentecostalism (Hollenweger 1997, 18-19), becoming an attractive drawcard that drew new adherents, serving to appeal to people across cultural boundaries (Botha 2007, 311). While Western Pentecostalism probably does not grant healing such a prominent role as in earlier times, in the Majority World the existence of disease and evil affects most people and requires real action from the church as well (Anderson, A.H. 2003, 6). For a discussion of the importance of healing, healing movements and ministers of healing in Pentecostal circles, cf. Burgess and McGee (1988, 350-374). 


\section{LAKE'S LIFE BEFORE HIS MISSION TO SOUTH AFRICA}

Lake's son-in-law, Wilford Reidt, wrote a biography of Lake where he mentions that Lake studied successfully for the ministry in the Methodist Church, allowing him to be appointed as pastor of a church in Peshtigo, Wisconsin. ${ }^{15}$ Shortly after entering ministry he decided to exchange it for a business venture when he founded a newspaper, The Harvey Citizen. He also set up a successful real estate business and helped found another paper, The Soo Times. In 1901, Lake moved to Zion City, ${ }_{16}^{16}$ John Alexander Dowie's utopia, ${ }^{17}$ where he was in charge of the church's construction

15 Morton (2012b, 82) makes the assertion that the Methodist seminary that Reidt referred to had never in fact existed, without providing any proof. Fact of the matter is that Lake (or Reidt) never mentioned the name of the seminary, illustrating Morton's biased interpretation of Lake. Morton $(2014 b, 5)$ is also convinced that Lake was, 'to put it simply', not an ordained minister, 'although he wished to appear as one from his early 20 s onwards.' No proof of the assertion is provided by the historian.

16 In 1886, at the age of 16, Lake saw how somebody close to him, probably his 22-year old brother, was healed, leading Lake to trust God for healing him from his own chronic constipation, and the resultant resolution not to make use of any medicine (Lake 1968, 5). Morton (2014b, 4) opines that Lake's chronic constipation 'was almost certainly an invention', without providing any documentation for his opinion. By 1896, Lake's wife was diagnosed with consumption, and subsequently became paralysed. On 28 April 1898, Lake with the support of friends from Dowie's church, offered up prayers for the healing of his wife from tuberculosis (Synan 2006, 6). Cf. Morton (2014b, 15-17) for a negative critical discussion of her healing. Lake became convinced of God's healing powers and moved in 1901 to Zion City in order to study divine healing (Susanto and Theron 2008, 174). He served as an elder in the Zion Catholic Apostolic Church until 1904 (Morton 2014b, 18 asserts that he never rose to a prominent position in the Zionist church but remained a deacon until Dowie's demise in 1905). Morton (2013a, 1) calls Dowie's Christian Catholic Apostolic Church in Zion 'essentially a criminal organization', based on what he describes as the economic strategies of the major Zionist churches. Morton (2013b, 9) concedes that Dowie's revenue came from a 'legitimate source', tithing. The economic strategy after Dowie's death went through two distinct phases, with at the beginning a small, core following and using their contributions to obtain agricultural land and creating a self-sufficient agrarianism, followed from the 1950s by a pragmatic period with large-scale membership increases and the utilisation of capitalist practices by promoting business formation among their members and forming their largely unskilled members into a kind of 'labor aristocracy' (Morton, 2013a, 12). These practices allowed the Zionist leaders like J.G. Shembe, Solomon Lion, Christina Nku, Edward Lekganyane, and Daniel Nkonyane to drive large fleets of chauffeured automobiles, go to universities, travel around the world, and dress themselves and their entourage in expensive attire. They live in large and prestigious residences, have considerable agricultural and business holdings, which they manage with the help of white lawyers (Morton 2013a, 8-9). Because their church funding is Mobutuist in nature, bitter disputes tend to be fought over succession by the leaders' children (Morton 2013a, 9). Morton's allegations about the Zionist church deserve to be investigated further.

17 Dowie opened his new utopian community at Zion, north of Chicago, in 1901. Dowie owned the city and leased out residences to his congregation. Lake purchased a lease in May 1901 (Morton 2014b, 18). 
department (Lake 1994, 89, 269; Liardon 1999, 10; Reidt 1989, 14-16). In 1904 he bought a seat on the Chicago Board of Trade and handled a railroad magnate, Jim Hill's Western Canadian land (Reidt 1989, 14). Lake was also employed to form a trust of three large insurance companies and served as manager of the trust (Reidt $1989,15)$. Although Lake was involved in part-time ministry he concluded that he was called to get into full-time ministry. Late in 1907 he disposed of his possessions and used the money to meet the need of others (Reidt 1989, 16; Copeland (1994, $\mathrm{xix}-\mathrm{xx}) .{ }^{18}$

Morton (2012a, 102) describes Lake's alleged sacrifice to abandon a business career earning him a good income in order to enter the full-time ministry ${ }^{19}$ as a myth that he used in order to legitimate his ministry and create a religious aura that 'stirred up a sense of awe and wonder amongst credulous audiences' ${ }^{20}$ Lake's claims about his business career and prosperity are false, argues Morton (2012a, 103), with evidence showing that he had only small contracts and did not even bid on public contracts nor advertise his contracting company in any newspapers. His real-estate activities did not include ownership of any large buildings but consisted of buying dilapidated properties that he fixed and sold for a profit. He also was not involved in any way in any newspaper that he claimed to have founded. And Lake did not supervise construction endeavours in Zion City, but was appointed as a repairman in the department (Morton 2014b, 18). To prove his points Morton utilises newspapers of the time as well as the church directories published regularly in Zion Banner from 1901 to 1906 . Lake claimed to have moved to Chicago in 1904 where he quickly

18 In her biography of Lake, Copeland obviously relies heavily on Reidt for her facts.

19 Lake grounded his decision to abandon his business ventures in order to give all his attention to the ministry in the examples of George Muller and Hudson Taylor (Tannenberg 1999, 12). Lake interpreted the rediscovery of the charismata or pneumatikoi as the restoration to the Church of the absolutely vital component that characterised the early Church and that would provide the missionary thrust that would result in an unprecedented 'harvest of souls' before the parousia (Allen 2007, 119; Land 1993, 6). Pentecostals share a restorationist primitivist drive (Klaus 2006, 2). Lake's mission was biblical, passionate, in the power of the Spirit, Christo-centric, and urgent, according to Klaus (2006, 3-4).

20 Morton (2012b, 73) argues that although Isaiah Shembe credited only one man for his religious development, William Leshega who had Shembe ordained as a preacher in the African Native Baptist Church, Shembe was directly impacted by Zionist ideas and individuals. The narratives of Shembe's early life and calling, as recorded in the 'Book of the Birth of Isaiah Shembe' and other documents, are shaped along the same lines as Lake's (Morton 2012b, 79, 88) and created Moseslike legends (Morton 2013a, 1). It is from Lake that Shembe also learned how to orchestrate religious fraud while they worked together in the Free State in 1910. 'Lake and his coterie at the helm of the AFM were all consummate con men who relied to some extent on assistants and placemen to aid them in conducting fraudulent faith healings and other cons' (Morton 2012b, 79). To prove his point that Lake placed assistants within the audience to provide him with information and to facilitate false healings, Morton refers to the assertions he made in another article (Morton 2012a, 109-114), where he also does not use any form of documentation. These conclusions are based on a methodology that is dubious and unacceptable. 
became a millionaire and purchased a seat on the Chicago Board of Trade. However, Morton is of the opinion that Lake remained in Zion City until 1907 although he quit his job as repairman in 1905 and worked as a salesman for a local real estate speculator in a nearby town, Waukegan, while also marketing fire and life insurance. A biographer of Lake, Burpeau $(2004,57)$, acknowledges that no evidence outside of Lake's own assertions has been found to verify that Lake was involved in business or industrial circles in Chicago. Instead of being a wealthy man, Lake was an insurance salesman, concludes Morton (2012a, 104). Morton's use of available resources is limited to a few newspaper articles to prove that Lake exaggerated or lied about his business ventures. No primary research was done to find data from available banks and local authorities and Morton's conclusion is based on a lack of any mentioning of Lake in available newspapers. However, as will be ascertained at a later stage, Lake was prone to exaggerate and it might be the case that his involvement in certain business ventures might have been limited. ${ }^{21}$ However, to conclude that Lake's reference to a lucrative business career that he abandoned in obedience to God's voice is a myth, and that Lake used to legitimise his leadership role in the Pentecostal fray, is to read into a lack of data too much.

\section{LAKE'S LIFE IN ZION CITY}

Morton (2012a, 104) alleges that Lake who settled in Zion City in order to acquaint himself better with the doctrine and practice of divine healing, fled in 1907 from Zion City after his 'involvement in highly unsavoury affairs' and that he used his story of a direct communication and revelation from the Spirit to depart for Africa in order to justify his leaving of Zion City as a means to remove attention from the 'real facts'. What occurred, according to Morton, is that Lake became embroiled in the polarisation that occurred in Zion City after the death of Dowie, and the resulting split of his church into various factions. Charles Parham resided intermittently in Zion City in late 1906 and he used the opportunity to preach his Pentecostal message of speaking in tongues as initial evidence for being baptised in the Spirit (Friesen 2009, 45; Hudson 2008, 149). Approximately 3500 Zionists joined his faction as a result of the revival services that he held in 1906, and they were baptised with the Spirit, with Lake and Hezmalhalch as prominent members (Parham 1930, 148-160, 171-177). 'From Zion came a host of almost 500 preachers who entered the ranks of the Pentecostal movement, chief of whom was John G. Lake' (Synan 1997, 138). Parham left Zion City and never returned when a water tower collapsed and destroyed

21 Lake was not the only one prone to exaggerate. Anderson, R.M. $(1979,94)$ provides an example of such exaggerations in early Pentecostal editors' refusal to print reports about purported divine healings without substantive proof; usually the testimony of some Pentecostal whose word the editor in question was willing to accept. Donald Gee was involved in the Pentecostal movement for 40 years and remarked that the small number of definite miracles of healing compared to the great numbers who were prayed for, made him sad (Gee 1928, 13). 
his revival tent. ${ }^{22}$ His followers experienced opposition from Dowie's successor, W.G. Voliva. Tom Hezmalhalch, one of the leaders of the Pentecostal followers in Zion City, invited William Seymour to visit the city (Morton 2012a, 105). Parham's followers continued to support him financially and they stayed loyal to him, even in the face of opposition from the other inhabitants of Zion City. The Parhamites' services were characterised by an 'apparent descent into a collective frenzy of insanity, demon possession, and murder' (Morton 2012a, 106). Morton connects it to Parham's arrest in Texas for the alleged soliciting of sex from a teenager that confirmed rumours that had been circulating about Parham's pederastic tendencies. Morton does not provide any evidence of these charges against Parham, although he admits that Goff's $(1988,137-138,224-225)$ research did not yield any proven facts about the charges. ${ }^{23}$ In this period nine Parhamites, seven women and two boys, were 'possessed by demons' (Morton 2012a, 106), an observation that Morton gets from a local newspaper that published over many years the most negative information about Zion City, Indianapolis News (22 September 1907, 3). ${ }^{24}$ Voliva called the Parhamites 'intoxicated', 'demon-inspired', 'a fanatical sect', 'an abomination' and a 'barbarian horde' (Zion Herald, 2 August 1907, 1). That the Parhamites became demon-possessed and insane was a charge laid by Voliva and utilised by Morton to prove that Lake became part of an unstable group.

The Parhamites ministered to what they perceived to be demon-possessed persons. ${ }^{25}$ At times they used physical force to expel the demon from the body, leading to the death of two persons, although Morton (2012a, 107) admits that Lake and Hezmalhalch were not involved. Because the undertaker was a Parhamite he did not register the deaths as unnatural. As evidence of these deaths Morton quotes from the Chicago Tribune of 24 May 1900, 3 June 1900, and 9 June 1900. However, these deaths should have occurred in Morton's chronology in 1907 when he claims that Lake and Hezmalhalch fled from Zion City due to possible prosecution resulting from these deaths, although it is clear that they were not involved with any of the cases. Morton also refers to the case of Letitia Greenhaulgh who died during an exorcism rite; although Lake was not involved with this case either. It was reported widely in the American press. Morton's contention that Lake did not leave Zion City

22 Voliva refused Dowie permission to use any of the worship facilities in Zion (Morton 2014b, 23).

23 Synan (1971, 99-100, n. 12) notes that while most Pentecostal writers acknowledge that Parham was partly responsible for formulating early Pentecostal doctrine, none of them accepted him as the 'father' of the movement; questions about his later personal ethics led to his place in Pentecostal history to be de-emphasised.

24 Another source that Morton uses is the Zion Herald, a newspaper published by the Voliva faction that opposed the Parhamites in the leadership struggle that characterised the period after the demise of Dowie and providing negative publicity about the Parham faction.

25 Cf. Thomas 2010, 296-299 for a discussion of the Pentecostals' perception of demons as a source of infirmity. 
in response to divine calling but to escape popular justice, is not reflected by the available facts but by a biased reading of the facts.

\section{LAKE'S MISSIONARY TOUR TO SOUTHERN AFRICA ${ }^{26}$}

Again, Morton (2012a, 100) finds in the narratives describing the missionary party's coming to southern Africa 'fraud and misrepresentation' that were 'central to the early spread' of Pentecostalism and Zionism in South Africa. Morton does not make a proper distinction or differentiation between the origins of Zionism in South Africa, with Johannes Büchler as well as Daniel Bryant and other missionaries sent to the continent by Dowie in 1904 and Pieter L. Le Roux's contribution (Wessels 1992, 372-374), and the eventual establishment of a Zionist branch of the AFM from some of these black Zionist assemblies - and in time also the African Pentecostal churches (Burger 1987, 109-110). ${ }^{27}$

Eventually, Hezmalhalch and Lake would leave for South Africa with 17 members including three other missionaries. ${ }^{28}$ Their tour was financed by contributions from believers in the USA. However, Morton (2012a, 102) argues that Lake told fellow passengers and the wider Pentecostal community of his mission and that he desperately needed funds to complete it. He concludes that Lake defrauded the steamship company and even stole existing funds, but does not provide any evidence at all for the assertions. In this way he implies that the coming of the missionaries to South Africa was based on and driven by dishonesty and fraudulence, throwing their missionary endeavours as well the result of their work in a bad light.

Morton (2012a, 109) contends that Lake and Bryant had dealings even before Bryant decided to leave South Africa. Bryant was one of Dowie's missionaries to South Africa and he had developed the biggest foreign Zionist congregation in Doornfontein, Johannesburg as well as in other cities (Oosthuizen 1987, 14-18; Sundkler 1976, 34-41). Bryant contended for Zionist leadership when Dowie died

26 Lake's missionary group was not the first to bring the Pentecostal message to South Africa. According to McGee $(2007,1)$, the earliest-known Pentecostal missionaries came to South Africa in 1904. Mary Johnson, Augusta Johnson and Ida Anderson left America for Africa in October 1904 and worked in Pondo Land (Thompson 1937, 8).

27 Anderson (2012a, 30) explains that there are clear affinities and common historical and theological origins shared by African and classic Pentecostals, but the passing of time and the proliferation of African Initiated Churches (AICs) have accentuated the differences. In spite of their historical connection to classical Pentecostalism, these churches differ in many respects from classical Pentecostal churches, for instance, in the use of healing symbolism, forms of government and hierarchical structures of leadership, the wearing of distinctive uniforms, and different approaches to African religions and culture (Anderson 2012a, 30-31). Cox (1995, 246) emphasises the importance of 'African expressions of the worldwide Pentecostal movement' (cf. Asamoah-Gyadu 2013b, 144)

28 McGee $(2012,36-37)$ refers to the diligence of these early Pentecostal missionaries and the challenges that they faced. 
and when he was succeeded by his hated rival Voliva, Bryant and his South African congregations left the Zionist church (Morton 2012a, 109). When Bryant returned to California, Lake and Hezmalhalch were invited to take the services at his church in Doornfontein, and when the AFM was founded, these three Zionist assemblies became the first AFM assemblies (Burger 1987, 173; 1997, 184) ${ }^{29}$ Lake and Bryant cooperated in several projects when they were both mid-level officials of Dowie's church, and Morton argues that they orchestrated a take-over of the Johannesburg assembly, although Lake never mentioned it and no other source refers to it (Burger 1987, 168). Morton's (2012a, 109) contention, 'Everything points to a carefullyorchestrated move to South Africa, rather than an impulsive, divinely-inspired one', does not hold water as it is based on abstractions without any facts to support it.

\section{LAKE IN SOUTH AFRICA}

Morton (2012a, 109) states that Lake (as well as the early leadership of the AFM) made himself guilty of fraudulent and lying behaviour in order to attract members to their church that would pay tithes..$^{30}$ The ultimate goal of their missionary work was to generate money for private enrichment. ${ }^{31}$ To succeed in the goal it was necessary for Lake to create a 'fictitious religious persona' that he crafted for himself, and he utilised an array of deceptions. 'Even in the event that Lake was a fervent Pentecostal at heart, nevertheless conscious deception lay at the centre of the religious activities of which he took charge' (Morton 2012a, 100). ${ }^{32}$ Another supposition that Morton

29 Comaroff $(1985,11)$ calls the ministry of Lake's evangelical team the 'second evangelization' to emphasise the link between Dowie's missionary enterprises in South Africa and Lake's continuation (De Wet, 1989, 34)

30 Fact is that Lake served as a champion of the poor and possessed, argues Anderson, A.H. (2003, 3 ), and the AFM grew exponentially amongst the dispossessed African and poor white Afrikaner victims of the defeat of the Anglo-Boer War (1899-1902) (De Wet 1989, 39)

31 The implication is that Lake and his missionary community were not interested in spreading the gospel, or witnessing to their experience of the baptism with the Spirit, but that their only interest was in personal enrichment. However, early Pentecostals viewed the baptism with the Spirit as empowerment for witness, and when all have heard then the end would come (Lewis 2001, 2). When the minutes of early meetings of the AFM are studied, it becomes clear that the early AFM represented poor people and that the church handled small amounts of money, leading to small remuneration of employees, including its leadership (Burger and Nel 2008, 60-61). In the same way, Morton $(2012 b, 91)$ states that 'obtaining money was Shembe's primary motivation', an allegation that is based on a psychological analysis of the person without providing any proof or evidence, and that links Shembe and Lake in the sense that Shembe used Lake as a model for his own ministry. 'The history of Shembe and his dynastic successors offer grounds for believing him to be an opportunist who created the Nazarite Church primarily for his own and his family's interest.' The wholesale generalisation about the history of the church is not discussed in terms of documenting any evidence that proves that the Shembe family was enriched unfairly.

32 Morton (2012a, 100), however, admits that it is impossible to tell whether Lake himself believed in the religious messages that he propagated. 
(2012a, 100, 102, 109) uses is that Lake learned from John Alexander Dowie's original Zionist church, in the decade prior to his South African mission, the roguery and knavery that would characterise his ministry. ${ }^{33} \mathrm{He}$ refers specifically to the utilisation of false testimonies ${ }^{34}$ about miraculous faith healing cures, ${ }^{35}$ the claim of raising the dead by which the divine healer proposed to have demonstrated his spiritual power, and the technique of precognition, consisting of the assistance of another person that would predict the imminent arrival of strangers with unusual powers.

Lake's advertising promised that people attending the meetings will be baptised in the Spirit with signs following and that the sick will experience miraculous healings (cf. broadsheets reprinted in Liardon 1999, 43), creating an expectation of

33 'He [Lake] also made use of the full panoply of Dowieite tricks, ranging through all variations of the "fake cripple", the "distant miracle", the "supernatural showdown", and healing those afflicted by cancer through "tumor extraction"' (Morton 2013b, 14). Morton (2015, 13-16) lists 'categories of deception in public healing ceremonies': false testimony, fake cripple, epileptic eruption, distant cure, tumour extraction, and supernatural showdowns. In the same way, Lake taught his South African followers such as Edward Lion, E.H. Mahon, Engenas Lekganyane, and Isaiah Sheme how to become adept at staging 'miracles' (Morton 2012b, 85; 2014a, 44). These lessons included that one should pray for healing at the start of the service, in order that the signs and wonders would catch the attention of the crowd and increase their vulnerability to placebo cures. A 'fake cripple' or paralysed in a wheelchair, the dumb, deaf, or blind are then prayed for, healed, and then able to demonstrate to the crowd their new ability to run around, speak, hear, or see. Or a 'devil-possessed' person would be brought in chains or in some similarly dramatic condition, the devils would be cast out, and sanity restored to the afflicted. A third method is the so-called 'distant miracle', where the preacher persuaded the crowd that their prayers would lead to a miracle somewhere else, as when Lake claimed that his prayers led to the Queen of the Netherlands to become pregnant (Lindsay 1972, 245-246). A final example is prayer for the dead, with Lake claiming to have experienced five dead people being restored to life during his stay in South Africa (Blake 2005, 160-161). It is clear that Morton does not allow for any of these 'healings' to have occurred at all.

34 'Many of these (miracles) can be proved to be complete fabrications' (Morton 2013b, 14). He gives two examples of such 'fabrications': that Lake was involved in Maggie Truter's resurrection (discussed elsewhere in the article), and the successes of Lake's evangelical expedition to the Limpopo region in 1909 with Elias Letwaba. However, Letwaba testified to these miracles (Chandomba 2007, 21). Morton (2014b, 12) asserts that Lake's function in Dowie's healing services was to organise false testimonials about healings and to act as an audience plant (such as by impersonating a minister) for Dowie. For this reason, 'there can be no doubt that the majority of the Lake family ended up by providing false healing testimonies for him [Lake] later on' (Morton 2014b, 12). Again, Morton does not document any of his assertions, indicating his lack of a valid historical method.

35 It should be noted that Dowie as well as Lake preferred for specific reasons not to refer to 'faith healing' but to 'divine healing' in order to emphasise that healing is not dependent on the minister or sick person's faith, but is a divine prerogative (Nel 2006, 266). Morton $(2012 \mathrm{~b}, 89)$ states with conviction that Shembe also used false testimonies to impress crowds; without providing any evidence of such false testimonies or how they were preserved. Morton's prejudiced sceptical view of miraculous healing disqualifies him to allow for any such miracles to occur; unfortunately he does not think it necessary to document his allegations. 
miracles. ${ }^{36}$ Morton (2012a, 110) allows for placebo cures from psychosomatic illnesses ('often-times spectacular') to have occurred. ${ }^{37}$ Nevertheless, the other 'signs and wonders' were staged (Morton 2012a, 110) ${ }^{38}$ The reason why Morton does not accept that real healings could have taken place, is his acceptance of a scientific worldview that does not allow for any supernatural phenomena to occur outside the accepted system of indictable cause and effect (cf. Ehrman and Licona 2009; Lataster 2013, 31). ${ }^{39}$ For this reason, Morton views it as a scam when Lake decorated the altar of his Johannesburg Tabernacle with crutches and therapeutic devices

36 Susanto and Theron $(2008,175)$ show how it was divine love for the suffering that worked through Lake and made his ministry effective because it allowed him to identify with the afflicted and to feel in a physical manner the same pain as the sufferers did. His faith led to a compassionate love toward the sick and faith that they could be helped (Susanto and Theron 2008, 179).

37 'Using their prophetic mystique to best advantage, they (faith healers) used the placebo effect to heal credulous devotees afflicted with psychosomatic illnesses and then turned them into their first followers' (Morton 2013a, 1). It is true that first converts joined the movement due to divine healing and various miracles (Anderson, A.H. 1992, 43; Daneel 1970, 16; Vilikazi, Mthethwa and Mpanza 1986, 45). 'Faith healing can cure psychosomatic diseases such as depression and anxiety, given the right circumstances that faith healers train themselves to create' (Morton 2014b, 2 ). The danger for the cured is that they will be exploited by the faith healer and his cult. Morton $(2014 b, 2)$ motivates his research in Lake by stating his desire to convince, if only even a single person, to avoid seeking out a faith healing cure.

38 According to Morton (2012b, 83-85), faith healers have to master two different skills in order to be successful. Firstly they must be able to create an atmosphere in which people would be gullible enough to accept placebo cures. A large percentage of illness is psychosomatic, and faith healers could cause instant cures to these diseases if they know how to utilise people's credulity. The correct setting consists of a large, expectant, emotional crowd free of sceptics. The atmosphere is created by invented testimonies about the way the faith healers were called. Secondly, the faith healer must look out for individuals susceptible to a placebo cure. It is crucial that the candidate does not know the faith healer, except by reputation. It is a fact that faith healers lose their ability to cure when people know them for any period of time. Morton's psychological analysis of the healing event is informed by his presupposition that no divine healings can occur, against the background of a scientific worldview that does not allow for any events to occur that cannot be explained according to cause and effect. He (Morton 2014b, 1-2) refers to centuries of scientific studies that faith healing and prayer cannot cure any organic disease or condition; still, he complains, many people keep on seeking out quacks for treatment.

39 Morton (2012a) refers to Lake in the title of his paper as 'The devil who heals', a remark that Lake himself made during his stay in South Africa. At one stage, Lake in Liardon $(2005,173)$ defended himself against accusations that healings which occurred during his meetings were not divine. Some people asserted that he was possessed of a devil and that people got saved and healed through diabolical powers: 'They now openly say it is the devil who heals.' It seems as though Morton would ascribe Lake's healing powers to evil forces. Jesus was accused in the same manner (Matt 12:24; Luk 11:15). 
supposedly discarded by the formerly disabled ${ }^{40}$ or when he demonstrated healing by the crippled person walking on-stage, as was the claim of 'distant miracles' with people being cured as far away as England and Iowa. ${ }^{41}$ Lake also claimed that several resurrections took place. Maggie Truter, the stepdaughter of a former minister of the Dutch Reformed Church, R.H. van de Wall, who joined the AFM and later became its general secretary, was ill in July 1909. When she died Lake prayed for her and she was restored to life (diary of Lake, 6 December 1910). ${ }^{42}$ Later, Maggie's mother described the event without referring to Lake, leading Morton (2012a, 112) to conclude that Lake was not involved in the miracle healing. However, in her account she does not refer to any minister by name and the inference is that Lake may have been a part of the team ministering to the daughter. Similar resurrections occurred during an expedition to the Waterberg region in May/June 1909 when Lake and Elias Letwaba visited the area (as reported in The Apostolic Faith, November/ December 1909, 11). ${ }^{43}$

Lastly, Morton claims that Lake utilised precognition, which proved particularly successful in rural areas. ${ }^{44}$ In one such case, the mother of the chief of a village dreamt that white men would visit the region at a certain date and time and that they should be received because they represent the Lord. The lady would announce what she perceived as a message of the Lord. When the missionaries arrived they would be met with great expectations and their message accepted (Blake 2005, 92-93). Morton's (2012a, 113) judgment is that these events were arranged by the

40 Dowie (Morton 2013b, 6) as well as Shembe placed used and discarded crutches all over the altar of their churches as Lake did. In the same way Shembe regularly used the once-crippled teenager Peter Mnqayi, whose ability to walk was 'allegedly' restored after Shembe's prayers (Hexham and Oosthuizen 1994, 41). Morton (2012b, 87) describes the 'primary effect' to be to make credulous audiences believe that the healer can render the crippled back to a state of physical prowess.

41 During 1911 there were 2032 cases of confirmed healings in the AFM, as published in the church magazine, Comforter (February 1912, 5). The church required proof of healing from the leader of the local assembly. The official church magazine published, right from its inception, a number of testimonies by people who were healed (Burger and Nel 2008, 56), a practice that was continued for many years. Botha $(2007,309)$ argues that Pentecostals' innovative use of media from its earliest days is one of the reasons for its success (see also Kalu 2008, 139).

42 Morton (2012a, 112) judges that Lake's “"diary" appears to have existed in part for him to invent various miracles and events that he could use in sermons and publications'. While it is true that Lake referred in later publications and sermons to the events that occurred in South Africa, Morton's judgment of Lake's diary entries as 'inventions' is a value judgment that does not do justice to the task of the historian and demonstrates the unwillingness of the historian to accept the validity of any miracles.

43 This is not the place to argue the historical validity of the so-called miracles that presumably took place in Lake's ministry. At most, the sources can be quoted that described these events while it must be remembered that they were written by believers who expected 'supernatural interventions' and in that sense were prejudiced towards the value of people's witnesses to healing and Lake's supposed ministry of healing.

44 Cf. Alvarsson's $(2007,184-187)$ critical discussion of divination among Pentecostals and their questioning of it as magic, when it is not entirely from a biblical or quasi-biblical context. 
missionaries and that it did not occur in fact, a supposition that is not supported by available facts.

When miracles take place, there is always the danger that expectations will reach such a pitch that human factors of ecstasy and mass suggestion may somehow enter the picture. The early AFM did experience its problems and reacted to it on the highest level (De Wet 1989, 77). Already on 22 January 1909 the Executive Council, the newly found church's highest controlling body, read a letter from a brother Schneiderman that states his reasons for having dissociated himself from the church. He points out that 'a great deal of very sad exaggerations in cases of healing had been made; that messages had been given not by God, etc., and that the Name of God was dishonoured thereby' (Burger and Nel 2008, 58). After a lengthy discussion the Council concluded that 'there was only too much truth in the letter', and resolved 'in future to use the utmost caution and to do all in our power with the help of God to eliminate from the work whatsoever was not of God; and to admit to the public that many mistakes had been made, even if such a confession cost humiliation' (Minutes of the Executive Council, 22 January 1909). It is true that the early AFM suffered from deficiencies and imperfections, although an attitude of honourableness and sincerity seems to be present (Burger and Nel 2008, 58).

The emphasis on divine healing as a part of the atonement led during the first decades to rejection of medical help in any form (Dayton 1987, 129). To trust in medicine or other help prescribed by doctors was even seen as a form of unbelief and sin, 'to lean on the arm of the flesh' (Burger 1987, 180; cf. Cartledge 2008, 128). Members of the church would often witness that they had not been to a doctor for many years. It is deeply tragic and not justifiable in any way that some people, including children, suffered and even died due to the lack of medical help. For instance, in 1917 a couple of the AFM Krugersdorp under the leadership of Eva Stuart was charged because they had refused medical help for their child who was under age. The child died and the state claimed that the child could have been saved if the parents had allowed hospitalisation and medical care. The Botha couple was found guilty on the charge of culpable homicide and wilful neglect of the child and was given a fine. On 14 December 1917 the Executive Council of the AFM appealed but lost its case (Nel 1996, 249). ${ }^{45}$ At the General Council in 1918, where representatives of all assemblies met annually, the church called on all its members to sign a petition addressed to the government asking for an amendment in the Children's Protection Act (1913) which would make provision for 'granting exemption from use of medicines, etc. to those who belong to a recognised religious body against whose faith it is to use medicines' (Nel 1996, 249). Members were at the same time requested to donate toward meeting the costs of a 105 pounds of the Appeal Court case. The reason for the rejection of

45 Several other similar cases were heard in courts, as late as 1932 when parents in Port Elizabeth were also fined (Nel 1996, 249). 
medical help is formulated in a remark in the Minutes of the Workers' Conference of 2 April 1931:

It was pointed out that Divine Healing excludes the use of medicine and that we should take a strong stand against those who made a habit of the practice... Several testified to the power of God in healing their bodies because they put their entire trust in Him (Nel 1996, 250). ${ }^{46}$

\section{ACCUSATIONS OF CO-WORKERS AGAINST LAKE}

Morton (2012a, 114) refers to complaints about and accusations against Lake from South African co-workers that 'led to the secession of many white Pentecostals from the AFM'. However, the many secessions reported are not documented by Morton except for a reference to Burpeau (2004, 120-124). It is true that there were some accusations but these did not lead to secessions of groups leaving the AFM. The first accusation that Morton discusses is the 'propaganda' that Lake published in America witnessing about incredible events that were occurring in South Africa with 'desperate pleas for money'. When other missionaries from America arrived they found that Lake's Pentecostal campaign was based on false reports and they sent 'very disquieting reports' back to America and Europe about Lake. Morton (2012a, 114) acknowledges that none of these reports or letters were published and none of them are extant. No record of these missionaries or their disappointment with the 'Pentecostal campaign' in South Africa exists in records kept by the AFM in their books of minutes of meetings or their monthly magazine, leading to the conclusion that the assertion is a result of Morton's prejudice against the Pentecostal revival that originated in the work of the missionary company of which Lake was a member.

Another accusation was that Lake misappropriated funds that belonged to the AFM donated by Pentecostals in the USA and elsewhere. Only Lake and his party had access to cash, according to Morton (2012a, 114). However, the minutes of the meetings in the early AFM indicate that the church elected a treasurer and secretary at its earliest meetings and that individuals did not have access to money without the knowledge of the rest of the executive (Burger and Nel 2008, 44). It is true that the workers in assemblies earned little; however, it is also true that Lake, Hezmalhalch and the other American missionaries earned very little (Burger 1987, 181). Morton (2012a, 115) refers to 'Lake's penchant for deceit' that led him to install his brotherin-law as AFM treasurer, a remark that betrays the historian's prejudiced evaluation of Lake's character without providing the necessary evidence for such a sweeping

46 Lake also emphasised the need to live a healthy life. For instance, he forbade his followers the use of tobacco and alcohol, and also the eating of pork. It is also important to follow the guidelines provided in the Bible for healthy living (Nel 2014, 4). Dowie had already emphasised these taboos, and modern-day Zionists follow the same injunctions (Morton 2013b, 5-6). 
statement ${ }^{47} ;$ '... there are grounds for believing that Lake and his party made use of the vast majority of available funding for their own benefit' (Morton 2012a, 115), another remark that is not documented in terms of any resources. ${ }^{48}$ Morton (2013b, 15) admits that the AFM executive and the Executive Council exonerated Lake of these charges, but argues that Lake 'controlled' the executive. However, Lake was not even the chairperson; Hezmalhalch served as president and chairperson and Lake was elected to serve as vice-president (Burger and Nel 2008, 35). Morton (2013b, 15) also states that a large portion of the white membership seceded from the AFM when the church did not act against Lake, which is factually not true (Burger 1987, 204). 'There are very good grounds for believing that the charges laid against him were true', a statement that Morton $(2013 \mathrm{~b}, 15)$ documents by referring to his discussion in Morton (2012a, 114-15) where he also does not refer to any resources or provide any documentation. A last statement that Morton (2013b, 15) makes is that Lake was arrested following his return to the United States and sued for using his 'undue influence' to sell worthless securities to members of his congregation, and again the historian does not provide any evidence of such a court case and its outcome.

Other accusations stated by Morton (2012a, 115) are that Lake acted dictatorially in the same tradition as Dowie ('a second Dowie'), ${ }^{49}$ that he exaggerated the scope

47 The treasurer of the first Executive Council was H.M. Turney, about whom very little is known. He resigned, however, after six months and on 25 February 1910 Peter Moffat, John G. Lake's brother-in-law, was elected as new treasurer (Minutes of the Executive Council, 25 February 1909). From the minutes it is clear that the bookkeeping was transparent.

48 The donations for Lake's work came mostly from the Upper Room Mission in Los Angeles, led by George B. Studd. After giving due consideration to letters and reports about possible misuse of funds, the Upper Room Mission who supported Lake's work in South Africa made the following statement about the money sent (inter alia \$2,200 sent over from April to November 1910) to Lake: 'We sent it to Brother Lake with no conditions attached (except that it was not to be used for buying land, for building, or for secular education), because we had every confidence in his integrity and his ability to administer the money wisely and well for the work there. We have even greater confidence in him today, and if we had 1,000 dollars in our hands now, we would be very glad to send it to him. We have received a report of how the monies have been expended from the treasurer of the Apostolic Faith Mission in Johannesburg, Mr Peter Moffat, and we were perfectly satisfied that the funds have been well and carefully spent' (Minutes of the Committee, The Upper Room, November 1910, 2). Before this decision, Lake wrote to the Upper Room Mission explaining the AFM's modus operandi with regard to contributions received: 'We have a strong council of competent men over our work - men who can deal with any situation. The council appointed a treasurer to take charge of the monies connected with the local work. Offerings sent to me personally from overseas, or in my care, are administered by me, after advising with the brethren at hand, especially Brother Van de Wall. The treasurer's books include both the monies received locally for the support of the general work here, and they are open to inspection at any time' (Minutes of the Committee, The Upper Room, November 1910, 2).

49 Cf. Garrard's (2009, 90-91) accurate assessment of the dangers of leadership in the Pentecostal community where leadership, is built on perceptions of anointing, leading to difficulties in the building of trust between the leaders and congregations. Johns (2007, 131-136) discusses the effects of dictatorial leadership on Pentecostal congregations. 
and nature of his Pentecostal campaign (as stated above), and that Lake was a 'con man', 'an untrue man', who used occult powers in his activities. These last accusations were made by George Bowie and are quoted in the Rand Daily Mail of 18 November 1910 and 24 November 1910. However, the newspaper reported about the quibble between Bowie and Lake, and presented Bowie's opinion that is accepted by Morton as facts in order to discredit Lake. ${ }^{50}$

Morton (2012a, 115) also refers to Lake's 'close friendships with spiritualist con men' and his alleged communication with his dead wife via séance that 'created rumblings in AFM circles'. Instead of cultivating friendship with spiritualists and hypnotists, Lake at several instances confronted them in public and humiliated their supposed powers (Lindsay, 1972, 28). Morton also does not provide any documentation for the 'rumblings in AFM circles' and no such documentation exists.

After his wife's death several accusations against Lake were made of conducting adulterous relationships with women in his congregation (Burger and $\mathrm{Nel} 2008,42$ ). Morton (2012a, 115) is correct in stating that the leadership of the AFM investigated these rumours and accusations against Lake. The results of the investigations were

50 George Bowie was born in 1860 in Scotland and experienced the baptism of the Spirit in 1907. He joined the Bethel Pentecostal Assembly and they sent him to South Africa where he arrived in April 1910. He called his missionary endeavour the Pentecostal Mission ('Pinkster Zending' in Afrikaans) (Du Plessis 1984, 84). Eleazar Jenkins, a missionary from Wales, joined the church, as well as Archibald Cooper who left the AFM when he was not elected on the first Executive Council in May 1909. George Bowie did not have any relations with the AFM as such and his work was not the product of any schism from the AFM. Bowie became involved with the discord between Lake and Hezmalhalch (Burger 1987, 202-204). The causative factors of the discord are to be found in the personality differences and different approaches to the ministry between Lake and Hezmalhalch. Lake, although so much younger than Hezmalhalch, was the more prominent, the stronger leader with his dynamic personality and sensational ministry. If it had been Lake who was elected as first president of the AFM in 1909, the problems could possibly have been avoided. What needs to be considered was that the younger Lake with his individualism, his greater dynamism and aspirations, came too strongly to the foreground, attracted too much prominence and perhaps he took the initiative once too often. It would be only human for the older man to feel uncertain of himself under these circumstances, and even threatened. Against this background it then happened that certain people came to the fore with various rumours and complaints against Lake. These complaints and allegations were not started by Hezmalhalch, but he was influenced by them and he sided with the instigators of this campaign against Lake. All available evidence indicates that the allegations were false and that the inciters were simply malicious, as argued above. The persons who started the rumours were not AFM members. Prominent among them were George Bowie, Archibald Cooper and W.P Gillis (sometimes spelled 'Gillies') (Burger and Nel 2008, 43). No members of the AFM left to join the Pentecostal Mission except Cooper who started his own work for 18 months before he joined the Pentecostal Mission. Bowie's remarks about Lake came about when he involved himself with the disagreement between Lake and Hezmalhalch. Hezmalhalch did not join Bowie's church but returned to the USA. The name of the Pentecostal Mission was eventually changed to the Full Gospel Church in 1921 (Du Plessis 1984, 84). 
noted in minutes of the AFM and Lake was exonerated on all counts (Burger and Nel 2008, 48).

Morton's (2012a, 115) contention is that as a result of these accusations Lake lost significant support when many Pentecostal newspapers refused to print witnesses about healings from his office, and many white members of the AFM left to join other Pentecostal churches. ${ }^{51}$ This also led to Lake forcing Hezmalhalch and Lehman to leave the AFM. None of these remarks are documented by Morton in any way, an unacceptable practice of making conclusions without any proof.

\section{CONCLUDING REMARKS}

Lake's labours led to the establishment in South Africa of the Pentecostal movement, and specifically of the AFM of SA with 1.4 million members in South Africa and currently established in 29 countries of the world ${ }^{52}$ as well as African Pentecostal Churches, with somewhere between a third and a half of all southern African Christians now being members of these churches (Morton 2013a, 1)..$^{53}$ Morton (2012a, 115-116) claims that his analysis of historical sources demonstrates that Lake was a religious fraud, and that much of his sources had purposefully not been used by sympathetic religious historians to Lake's case before. As was shown, Morton utilises sources from newspapers that were critical about Dowie and newspaper reports about the opinion of Bowie when he left Lake. In most instances statements are not substantiated by any historical references. In this way the historian discredits Lake as well as the churches that flow from his work, as demonstrated by the way Morton (2012a, 116) ends his article, with a reference from the atheist journalist Christopher Hitchens $(2009,165)$ that such a story about the founder of a religious movement demonstrates what happens when a plain racket turns into a serious religion before our eyes.

51 After his return to the United States in 1912, Lake's ministry led to the formation of healing homes in Spokane, Washington and Portland, Oregon before he died in 1935 (Synan 2006, 6).

52 http://www.afm-ags.org/ (accessed on 6 June 2015).

53 The Zion Christian Church (ZCC) claimed by 1993 to have six million members, making it South Africa's largest Christian denomination (Synan 1997, 138). The church consists of the main ZCC star church and the splinter group Saint Engenas ZCC (Lukhaimane 1980, 1). In its annual Easter conference at Zion near Polokwane, the church gathers upwards of two million worshippers, the largest annual gathering of Christians on earth (Synan 2006, 6). Other churches include the St. John's Apostolic Faith Healing Church, the Masowe Apostles, and the Nazarites, all vibrant multinational enterprises known for their 'exuberant forms of sacred dress', 'massive annual gatherings', and 'noise-polluting all-night worship services' (Morton 2013b, 1). 


\section{REFERENCES}

Allen, D. 2007. Revival: A classic Pentecostal view. Journal of the European Pentecostal Theological Association 27(2): 118-127.

Alvarsson, J.Å. 2007. The Bible, Pentecostalism, and magic. Journal of the European Pentecostal Theological Association. 27(2): 183-196.

Anderson, A.H. 1991. Moya: The Holy Spirit in an African context. Pretoria: Unisa.

Anderson, A.H. 1992. Bazalwane: African Pentecostals in South Africa. Pretoria: Unisa.

Anderson, A.H. 1997. African Pentecostal churches and concepts of power. Paper read at the Africa Forum, Council of Churches for Britain and Ireland, April 1997, 1-4.

Anderson, A.H. 2000. Zion and Pentecost: The spirituality and experience of Pentecostals and Zionist/Apostolic churches in South Africa. African Initiatives in Christian Mission. Pretoria: University of South Africa.

Anderson, A.H. 2001. African Reformation: African initiated churches in the 20th century. Trenton, NJ: Africa World Press.

Anderson, A.H. 2003. Towards a Pentecostal missiology for the majority world. Paper presented at the International Symposium on Pentecostal Missiology, Asia-Pacific Theological Seminary, Baguio City, Philippines, 1-19.

Anderson, A.H.. 2007. Spreading fires: The missionary nature of early Pentecostalism. London: SCM.

Anderson, A.H. 2012a. African Pentecostalism. In Handbook of Pentecostal spirituality. Edited by A. Stewart, 27-31. DeKalb: Northern Illinois University Press.

Anderson, A.H. 2012b. William Joseph Seymour. In Handbook of Pentecostal spirituality. Edited by A. Steward, 186-189. DeKalb: Northern Illinois University Press.

Anderson, R.M. 1979. Vision of the disinherited: The making of American Pentecostalism. New York: Oxford University Press.

Asamoah-Gyadu, J.K. 2002. Pentecostalism in Africa and the changing face of Christian mission: Pentecostal/charismatic renewal movements in Ghana. Mission Studies 19(2): 14-39.

Asamoah-Gyadu, J.K. 2013a. Contemporary Pentecostal Christianity: Interpretations from an African context. Regnum studies in global Christianity. Eugene: WIPF \& STOCK.

Asamoah-Gyadu, J.K. 2013b. Pentecostalism and the influence of primal realities in Africa. In The many faces of global Pentecostalism. Edited by H.D. Hunter and N. Ormerod, 139-161. Cleveland: CPT.

Barrett, D. 1998. A century of growth. Christianity Today 42(16): 50-51.

Berglund, A.I. 1976. Zulu thought-patterns and symbolism. London: Hurst.

Blake, C. (ed.) 2005. John G. Lake's writings from Africa. Dallas: Xulon.

Blumhofer, E. 2006. Azusa Street revival. Christian Century 123(5): 20-22.

Botha, E. 2007. The New Reformation: The amazing rise of the Pentecostal-charismatic movement in the 20th century. Studia Historiae Ecclesiasticae 33(1): 295-325.

Bundy, D.D. 1990. Lindsay, Gordon (1906-1973) and Freda Schimpf Lindsay (1916-). In Dictionary of Christianity in America. Edited by D.G. Reid, R.D. Linder, B.L. Shelley and H.S. Stout, 341. Downers Grove: InterVarsity. 
Burger, I.S.V.D.M. 1987. Die geskiedenis van die Apostoliese Geloof Sending van Suid-Afrika (1908-1958). Published D.D. dissertation, University of Pretoria. Johannesburg: Gospel Publishers.

Burger, I.S.V.D.M. 1997. A historical perspective on the origin of the Apostolic Faith Mission of South Africa. In The reality of the Holy Spirit in the church: In honour of F.P. Möller. Edited by P.J. Gräbe and W.J. Hattingh, 175-191. Pretoria: J.L. van Schaik.

Burger, I. and Nel, M. 2008. The fire falls in Africa: A history of the Apostolic Faith Mission of South Africa. Vereeniging: Christian Art.

Burgess, S.M. and McGee, G.B. 1988. Dictionary of Pentecostal and charismatic movements. Grand Rapids: Zondervan.

Burpeau, K. 2004. God's showman: A historical study of John G. Lake and South African/ American Pentecostalism. Oslo: Refleks.

Cartledge, M. 2008. The early Pentecostal theology of Confidence magazine (1908-1926): A version of the five-fold gospel? Journal of the European Pentecostal Theological Association 28(2): 118-132.

Chandomba, L. 2007. The history of Apostolic Faith Mission and other Pentecostal missions in South Africa. Keynes: AuthorHouse.

Comaroff, J. 1985. Body of power, Spirit of resistance: The culture and history of a South African people. Chicago: University of Chicago Press.

Copeland, G. 1994. Foreword. In John G. Lake: His life, his sermons, his boldness of faith. Edited by J.G. Lake, xiii-xxx. Forth Worth: Kenneth Copeland Publications.

Cox, H. 1995. Fire from heaven: The rise of Pentecostal spirituality and the reshaping of religion in the twenty-first century. Reading, Mass: Addison-Wesley.

Daneel, M. 1970. Zionism and faith healing in Rhodesia: Aspects of African Independent Churches. Hague: Mouton.

Daneel, M.L. 1971. Old and new in Southern Shona independent churches. Vol. 1. The Hague: Mouton.

Dayton, D.W. 1987. Theological roots of Pentecostalism. Hendrickson: Peabody.

De Wet, C.R. 1989. The Apostolic Faith Mission in Africa 1908-1980: A case study in church growth in a segregated society. $\mathrm{PhD}$ dissertation, University of Cape Town.

Du Plessis, I.G.L. 1984. Pinkster-panorama: 'n Geskiedenis van die Volle Evangelie Kerk van God in Suidelike Afrika 1910-1983. Irene: Volle Evangelie Kerk van God.

Ehrman, B.D. and Licona, M. 2009. Debate: Can historians prove Jesus rose from the dead? Matthews: Southern Evangelical Seminary. DVD.

Friesen, A. 2009. The called out of the called out: Charles Parham's doctrine of Spirit baptism. The Journal of the European Pentecostal Theological Association 29(1): 43-55.

Gabriel, A.K. 2012. Neo-Pentecostalism. In Handbook of Pentecostal spirituality Edited by A. Stewart, 150-154. DeKalb: Northern Illinois University Press.

Garrard, D.J. 2009. Leadership versus the congregation in the Pentecostal/charismatic movement. Journal of the European Pentecostal Theological Association 29(2): 90-103

Gee, D. 1928. Pentecostal movement in Europe today. The Australian Evangel 2(12): 5, 10-13. 
Goff, J.R. 1988. Fields white unto harvest: Charles F. Parham and the missionary origins of Pentecostalism. Little Rock: University of Kansas Press.

Hammonds, R. 2009. The Pentecostal movement. Bloomington: AuthorHouse,

Harper, M. 2008. The early Pentecostal theology of Confidence magazine (1908-1926): A version of the fivefold gospel? Journal of the European Pentecostal Theological Association 28(2): 118-132.

Hexham, I. and Oosthuizen, G.C. (eds). 1994. The story of Isaiah Shembe, II: The scriptures of the amaNazaretha of EKuphakameni. Calgary: University of Calgary Press.

Hitchens, C. 2009. God is not great: How religion poisons everything. New York: Twelve.

Hollenweger, W.J. 1997. Pentecostalism: Origins and developments worldwide. Peabody: Hendrickson.

Hudson, N. 2008. Dealing with the fire: Early Pentecostal responses to the practices of speaking in tongues and spoken prophecy. Journal of the European Pentecostal Theological Association 28(2): 148-162.

Johns, K.D. 2007. The Pentecostal paradigm: A seductive paradise. Bloomington: Xlibris.

Joubert, S. 2013. Not by order, nor by dialogue: The metanoetic presence of the kingdom of God in a fluid new world and church. Acta Theologica 33(1): 114-134. DOI: http://dx.doi. org/10.4314/actat.v33i1.6

Kalu, O. 2008. African Pentecostalism: An introduction. New York: Oxford University Press.

Klaus, B.D. 2006. Pentecostalism and mission. Paper presented to the American Society of Missiology, Assemblies of God Theological Seminary, Springfield, Missouri, 1-18.

Lake, J G. 1968. Uit die dagboek van John G. Lake. Vertaal deur H J Scheepers. Trooster, 38, 5, 9-10.

Lake, J.G. 1981. Adventures in God. Tulsa: Harrison House.

Lake, J.G. 1994. John G. Lake: His life, his sermons, his boldness of faith. Forth Worth: Kenneth Copeland Publications.

Land, S.J. 1993. Pentecostal spirituality: A passion for the kingdom. Cleveland: CPT.

Landau, P. 2010. Politics in the history of South Africa, 1400-1948. Cambridge: Cambridge University Press.

Lataster, R.C. 2013. There was no Jesus, there is no God: A scholarly examination of the scientific, historical, and philosophical evidence and arguments for monotheism. Create Space Independent Publishing Platform.

Letson, H. 2007. Pentecostalism as a paradigm shift: A response to Hans Kung's paradigmatic model. Journal of the European Pentecostal Theological Association 27(2): 104-117.

Lewis, P.W. 2001. Reflections of a hundred years of Pentecostal theology. Paper presented at $9^{\text {th }}$ Annual William Menzies Lectureship at Asia Pacific Theological Seminary, Baguio, Philippines, 1-25.

Liardon, R. 1996. God's generals: Why they succeeded and why some failed. New Kensington: Whitaker House.

Liardon, R. 1999. John G. Lake: The complete collection of his life teachings. New Kensington: Whitaker House. 
Liardon, R. 2005. John G. Lake: The complete collection of his life teaching. New Kensington: Whitaker House.

Lindsay, G. 1972. John G. Lake, Apostle to Africa. Dallas: Christ for the Nations.

Lovett, L. 1975. Black origins of the Pentecostal movement. In Aspects of Pentecostal-charismatic origins. Edited by V. Synan, 129-144. Plainfield: Logos.

Lukhaimane, E.K. 1980. The Zion Christian Church of Ignatius Engenas Lekganyane 1924-1948: An African experiment with Christianity. MA dissertation, University of the North.

MacRobert, I. 1988. The black roots and white racism of early Pentecostalism in the USA. Basingstoke: Macmillan.

McGee, G.B. 1997. Power from in high: A historical perspective on the radical strategy of missions. In Pentecostalism in context. Edited by W. Ma and R.P. Menzies, 321-334. Sheffield: Sheffield Academic Press.

McGee, G.B. 2007. Brought into the sphere of the supernatural: How speaking in tongues empowered early Pentecostals. Encounter 4(1): 1-16. http://www.agts.edu/encounter/ articles/2007_fall/mcgee.htm (accessed on 10 May 2015).

McGee, G.B. 2012. Early Pentecostal missionaries: They went everywhere preaching the gospel. In Azusa Street and Beyond: Missional commentary on the global Pentecostal/charismatic movement. Edited by G. McClung, 35-40. Revised edition. Alachua: Bridge-Logos.

Minutes of the Committee, The Upper Room, November 1910.

Minutes of the Executive Council of the AFM of SA, 22 January 1909.

Minutes of the Executive Council of the AFM of SA, 25 February 1909.

Minutes of the Workers' Conference of the AFM of SA, 2 April 1931.

Morton, B. 2012a. The devil who heals: Fraud and falsification in the Evangelical Career of John G Lake, Missionary to South Africa 1908-1913. African Historical Review 44(2): 98-118. http://dx.doi.org/10.1080/17532523.2012.739752 (accessed on 23 May 2015).

Morton, B. 2012b. Shembe and the early Zionists: A Reappraisal. New Contree 69: 71-92. https:// www.academia.edu/7946640/Shembe_and_the_Early_Zionists_A_Reappraisal (accessed on 23 May 2015).

Morton, B. 2013a. Turning Zionists into workers: An exploration of the economic strategies of the major Zionist churches during the second evangelization. Paper presented at the $24^{\text {th }}$ biennial conference of the Southern African Historical Society, University of Botswana, Gaborone, 27-29 June 2013, 1-14. https://www.academia.edu/6779054/Turning_Zionists_into_ Workers_An_Exploration_of_the_Economic_Strategies_of_the_Major_Zionist_Churches during the_Second_Evangelization (accessed on 23 May 2015).

Morton, B. 2013b. The big con: John Alexander Dowie and the spread of Zionist Christianity in Southern Africa Paper. Paper presented at the University of Leiden, African Studies Center, 20 June 2013, 1-17. https://www.academia.edu/6779053/The_Big_Con_John_Alexander_ Dowie_and_the_Spread_of_Zionist_Christianity_in_Southern_Africa (accessed on 23 May 2015).

Morton, B. 2014a. The rebellion from below and the origins of early Zionist Christianity. African Historical Review 46(20): 25-47. DOI: 10.1080/17532523.2014.943924, 25-47. http://www. tandfonline.com/doi/abs/10.1080/17532523.2014.943924 (accessed on 23 May 2015). 
Morton, B. 2014b. John G Lake's formative years, 1870-1908: The making of a con man, 1-34. https://www.academia.edu/7005594/John_G_Lake_s_Formative_Years_1870-1908_The_ Making_of_A_Con_Man (accessed on 23 May 2015).

Morton, B. 2015. John Alexander Dowie and the invention of modern faith healing, 188289. Paper presented at Muckleneuk Campus, Unisa, 11 June 2015, 1-17. https://www. academia.edu/12444505/John_Alexander_Dowie_and_the_Invention_of_Modern_Faith_ Healing_1882-89 (accessed on 23 May 2015).

Murray, C. 1999. The Father, the Son and the Holy Spirit: Resistance and abuse in the life of Solomon Lion. Journal of Religion in South Africa 29(3): 341-386.

Nel, M. 1996. Eva Stuart: Woman pioneer in the Pentecostal movement. In Digging up our foremothers: Stories of women in Africa. Edited by C. Landman, 243-257. Pretoria: Unisa Press.

Nel, M. 2005. P.L. le Roux, Dutch Reformed missionary, Zionist preacher and leader of the Apostolic Faith Mission of South Africa, and the origin of some of the African Independent Churches in Southern Africa. Part 1. Ned Geref Teologiese Tydskrif 46(1-2): 200-208.

Nel, M. 2006. Vergelyking tussen die genesingsteologie van John G Lake en Hannes Jonker. Studia Historiae Ecclesiasticae 32(1): 263-284.

Nel, M. 2014. Implikasies van ontwikkelings in die leerstelling van goddelike genesing binne die Pinksterbeweging. In die Skriflig 48(1), Art. \#1792, 9 pages. http://dx.doi.org/10.4102/ids. v48i1.1792.

Oosthuizen, C.G, 1987. The birth of Christian Zionism in South Africa. Kwa-Dlangezwa: University of Zululand.

Parham, S. 1930. The life of Charles F. Parham: Founder of the Apostolic Faith Movement. Baxter Springs: Apostolic Faith Bible College.

Pate, L.D. 1991. Pentecostal missions from the two-thirds world. In Called and empowered: Global mission in Pentecostal perspective. Edited by M.A. Dempster, B.D. Klaus and D. Petersen, 242-248. Peabody: Hendrickson.

Reidt, W. 1989. John G. Lake: A man without compromise. Tulsa: Harrison House.

Sundkler, B.G.M. 1976. Zulu Zion and some Swazi Zionists. London: Oxford.

Susanto, J.L. and Theron, J. 2008. Compassion on people as a stimulus for the development of the church's healing ministry: Lessons from the lives of two Pentecostal pioneers. Studia Historiae Ecclesiasticae 34(2): 169-184.

Synan, V. 1971. The holiness-Pentecostal movements in the United States. Second edition. Grand Rapids: William B. Eerdmans.

Synan, V. 1997. The holiness-Pentecostal tradition: Charismatic movements in the twentieth century. Second edition. Grand Rapids: William B. Eerdmans.

Synan, V. 2001. The century of the Holy Spirit: 100 years of Pentecostal and charismatic renewal, 1901-2001. Nashville: Thomas Nelson.

Synan, V. 2006. The origins of the Pentecostal movement. http://www.oru.edu/library/special collections/holy_spirit_research_center/Pentecostal_history.php (accessed on 2 May 2015), $1-7$.

Tan-Chow, M.L. 2007. Pentecostal theology for the twenty-first century: Engaging with multifaith Singapore. Hampshire: Ashgate Publishing. 
Tannenberg, W.M. 1999. The healer: Dr. John Graham Lake. In John G. Lake: The complete collection of his life teachings. Edited by R. Liardon, 10-23. Tulsa, Oklahoma: Albury.

Thomas, J.C. 2010. The devil, disease and deliverance: Origins of illness in New Testament thought. Cleveland: CPT.

Thompson, P.B. 1937. A Pentecostal outpouring of thirty-four years ago. Pentecostal Evangel November 27: 8. http://ifphc.org/pdf/PentecostalEvangel/1930-1939/1937/1937_11_27. pdf\#Page8 (accessed on 6 June 2015).

Tickle, P. 2012. Emergence Christianity: What it is, where it is going, and why it matters. Grand Rapids: BakerBooks.

Turnage, M. 2003. The early church and the axis of history and Pentecostalism facing the $21^{\text {st }}$ century: Some reflections. Journal of the European Pentecostal Theological Association 223: 4-29.

Vilikazi, A., Mthethwa, M. and Mpanza, M. 1986. Shembe: The revitalization of African Society. Johannesburg: Skotaville.

Wessels, W.J. 1992. Skrifgebruik en samelewing: Die Apostoliese Geloofsending van SuidAfrika. In die Skriflig 26(3): 369-384. 